\section{Microstructural Study of Chilling Injury Alleviation by 1-Methylcyclopropene in Persimmon}

\author{
Isabel Pérez-Munuera and Isabel Hernando \\ Departamento de Tecnología de Alimentos-Universidad Politécnica de \\ Valencia, 46022, Valencia, Spain
}

\author{
Virginia Larrea \\ Instituto Universitario de Ingeniería de Alimentos para el Desarrollo- \\ Universidad Politécnica de Valencia, 46022, Valencia, Spain
}

Cristina Besada, Lucía Arnal, and Alejandra Salvador ${ }^{1}$

Departamento de Postcosecha, Instituto Valenciano de Investigaciones Agrarias, Carretera Monacada-Náquera, Km. 4.5, Moncada, 46113, Valencia, Spain

Additional index words. scanning electron microscopy, cell wall, intercellular adhesion, soluble tannins, astringency

\begin{abstract}
The storage of persimmon cv. Rojo Brillante (Diospyros kaki L.) at low temperatures is limited by the susceptibility to chilling injury $(\mathrm{CI})$, the main symptom being a drastic reduction of firmness when the fruit are transferred from low to moderate temperature. 1-Methylcyclopropene (1-MCP), an ethylene action inhibitor, has been shown to alleviate CI of persimmon, prolonging the storage period. In this article, the microstructural changes produced in the flesh of chilling-injured persimmon and fruit treated with 1-MCP were studied. The drastic softening displayed by chilling-injured fruit was related to a loss of cell wall integrity as well as to low intercellular adhesion. 1MCP treatment alleviated CI by preserving the fruit firmness; it was linked to a preservation of the cell wall's integrity and to a higher intercellular adhesion observed during storage at low temperatures as well as when fruit were transferred to shelf temperatures.
\end{abstract}

The persimmon cv. Rojo Brillante is astringent at the time of harvest and has a firm texture after being subjected to deastringency treatment with $95 \%$ to $98 \%$ of carbon dioxide $\left(\mathrm{CO}_{2}\right)$ (Arnal and Del Río, 2003). Soluble tannins are responsible for astringency of persimmon; condensation of tannins with acetaldehyde, which is metabolically produced under anaerobic conditions, generates insoluble polymers that are not astringent (Matsuo and Ito, 1982). Removal of astringency without firmness loss is a major objective for postharvest quality.

Like other cultivars, 'Rojo Brillante' is sensitive to cold storage; the main symptom of chilling injury (CI) is a drastic softening of the flesh, which occurs when the fruit is transferred from cold storage to shelf-life conditions. Sometimes, softening produced by $\mathrm{CI}$ is accompanied by gelification (Arnal and Del Río, 2004a). Various studies have related CI in persimmon to changes in cellular structure; a greater and more accelerated

Received for publication 10 Feb. 2009. Accepted for publication 16 Mar. 2009.

This research was supported by the spanish 'Ministerio de Educación y Ciencia (Proyect RTA200600028-00-00)' and the EU Feder program.

${ }^{1}$ To whom reprint requests should be addressed; e-mail asalvado@ivia.es. cell wall solubilization of chilling-injured fruit in comparison with normally ripened fruit at $20^{\circ} \mathrm{C}$ was reported in persimmon cv. Fuyu (Grant et al., 1992). Moreover, Luo and $\mathrm{Xi}$ (2005) reported that in chilling-injured fruit, the primary cell wall and the middle lamella could not be dissolved normally when the fruit were transferred to normal temperature after storage at $4{ }^{\circ} \mathrm{C}$. On the other hand, an electrical impedance study of several cellular structures showed that the fruit response to both ripening at $20{ }^{\circ} \mathrm{C}$ and storage at $7{ }^{\circ} \mathrm{C}$ is different (Harker and Forbes, 1997).

1-Methylcyclopropene (1-MCP), which is an inhibitor of ethylene action, has been shown to reduce CI symptoms of cold-stored persimmon (Girardi et al., 2003; Kim and Lee, 2005; Tibola et al., 2005). In 'Rojo Brillante', 1-MCP also alleviates CI when the fruit is stored at $1{ }^{\circ} \mathrm{C}$, delaying the softening of the flesh without a negative effect on fruit quality (Salvador et al., 2004).

$1-\mathrm{MCP}$ delays the softening of the persimmon during normal ripening at $20^{\circ} \mathrm{C}$, and this fact has been related to the inhibition of certain cell wall degrading enzymes (Luo, 2004, 2007; Luo and Xi, 2005; Niikawa et al., 2005; Xu et al., 2004). Furthermore, Kubo et al. (2003) associated the maintaining of firmness for a longer time in fruit treated with
1-MCP with a reduction of such enzymes mRNAs.

There are some studies on the preservation of cell structures by 1-MCP during cold storage of some commodities; in avocado fruit, Hershkovitz et al. (2005) observed, using an electrical conductivity (EC) technique, that the 1-MCP caused a reduction of $\mathrm{EC}$ in the tissue and reported that cold storage enhanced the process of membrane destruction, whereas 1-MCP treatment inhibited it. Similar effects of 1-MCP were found in climacteric pear (Larrigaudiere et al., 2004) and in Spanish melon (Valdenegro et al., 2005).

In the specific case of the persimmon, the relationship between the effectiveness of 1MCP to alleviate softening as the main CI symptom and the cellular structure of the fruit has been not studied. The study of the effect produced by 1-MCP treatment on the microstructure of persimmon flesh would help to understand the mechanism in the process of decreasing the symptoms of CI.

The objective of this article was to study the relationship between the beneficial effect that 1-MCP has on $\mathrm{CI}$ and the microstructural changes produced in the flesh of persimmon.

\section{Materials and Methods}

Plant material and treatments. Persimmon fruit cv. Rojo Brillante were picked at L'Alcudia (Valencia, Spain), transported to the experimental station where they were randomly divided into two groups of 200 fruits, and submitted to the following treatments: 1) control (air); and 2) exposed to 500 $\mathrm{nL} \cdot \mathrm{L}^{-1}$ of 1-MCP. Fruit from each treatment was stored at $1{ }^{\circ} \mathrm{C}, 85 \%$ to $95 \%$ relative humidity $(\mathrm{RH})$, up to $40 \mathrm{~d}$. Periodically (10, 20,30 , and $40 \mathrm{~d}$ ), two samples of 25 fruit per treatment were removed from the storage room. One sample was analyzed directly and the other one was submitted to deastringency treatment and then stored at $20{ }^{\circ} \mathrm{C}$ for $5 \mathrm{~d}$ to simulate the shelf life period.

1-MCP $\left(\right.$ SmartFresh $\left.^{\mathrm{TM}}\right)$, provided by AgroFresh Inc. (Rhom and Haas Inc., Gessate, Italy), is formulated as powder $(0.14 \%$ 1-MCP). The calculated quantity of SmartFresh needed to obtain the required 1-MCP concentration in each chamber was placed in a $125-\mathrm{mL}$ tight-sealed bottle and warm water $\left(16 \mathrm{~mL} \cdot \mathrm{g}^{-1}\right.$ product) was added through the septum. It was shaken in a warm water bath until the turbidity had disappeared $(\approx 40$ min). The sealed bottles were put inside each chamber and were opened just before closing it. The chambers were maintained sealed for $24 \mathrm{~h}$ at $1{ }^{\circ} \mathrm{C}$.

Deastringency treatment was carried out inside airtight containers, which contained $95 \%$ to $98 \% \mathrm{CO}_{2}$, for $24 \mathrm{~h}$ at $20{ }^{\circ} \mathrm{C}(90 \%$ $\mathrm{RH})$. The $\mathrm{CO}_{2}$ target concentration was established by passing a stream of air containing $95 \%$ to $98 \% \mathrm{CO}_{2}$ through the containers.

Fruit assessments. Firmness, soluble tannin content, and acetaldehyde concentration were analyzed at harvest after storage periods at $1{ }^{\circ} \mathrm{C}$ and after subsequent shelf life periods $\left(5 \mathrm{~d}\right.$ at $\left.20^{\circ} \mathrm{C}\right)$. 
Flesh firmness was evaluated with a Texturometer Instron Universal Machine model 4301 (Instron Corp., Canton, MA) using an 8$\mathrm{mm}$ plunger. Fruit firmness values were an average of 20 fruit per treatment. Results were expressed as load in Newtons $(\mathrm{N})$ to break the flesh in each fruit on $180^{\circ}$ sides after peel removal.

To determinate soluble tannins and acetaldehyde concentration, lots of 15 fruit per treatment were divided into three samples and cut into four longitudinal parts. Two opposite parts were sliced and frozen at $-20{ }^{\circ} \mathrm{C}$ to determine soluble tannins. The other opposite parts of the fruit were placed in an electric juice extractor and the filtered juice was then used to determine acetaldehyde concentration. Soluble tannins were evaluated using the Folin-Denis method (Taira, 1995) as described by Arnal and Del Río (2004b); the results were expressed in percentage of fresh weight. Three replicates of acetaldehyde concentration were measured per juice sample and analyzed by headspace gas chromatography as described by Salvador et al. (2004). Results were expressed as $\mathrm{mg} \cdot \mathrm{L}^{-1}$.

The data were subjected to analysis of variance, and multiple comparisons between means were determined by the least significant difference test $(P=0.05)$ using the Statgraphics Plus 5.1 software application (Manugistics Inc., Rockville, MD).

The scanning electron microscopy (SEM) technique was used to study the microstructure of persimmon. The microstructural study was carried out on persimmon samples stored at $1{ }^{\circ} \mathrm{C}$ up to $30 \mathrm{~d}$ as well as after the subsequent shelf life periods. Cubes $\left(3 \mathrm{~mm}^{3}\right)$ from the equatorial area of the persimmon flesh in the inner zone (at $2 \mathrm{~cm}$ of the skin) were cut with a stainless steel cutter. The cubes obtained were fixed (primary fixation with $2.5 \%$ glutaldehyde and secondary fixation with $2 \%$ osmium tetroxide) and dehydrated in a series of $10 \%, 20 \%, 40 \%, 60 \%$, $80 \%$, and $100 \%$ ethanol (ethanol/water, v/v) every $20 \mathrm{~min}$, rinsed in acetone, and ultradehydrated by critical point with $\mathrm{CO}_{2}(7584.23$ $\mathrm{kPa}, 31.5^{\circ} \mathrm{C}$ ) in a POLARON E3000 instrument (Watford, U.K.). Then they were goldcoated using POLARON E6100 Equipment (0.01 Pa, $20 \mathrm{~mA}, 80 \mathrm{~s})$ and observed in a JEOL JSM 6300 SEM (JEOL, Tokyo, Japan) at $15 \mathrm{kV}$ and a working distance of $15 \mathrm{~mm}$.

\section{Results and Discussion}

During storage at $1{ }^{\circ} \mathrm{C}$, firmness, soluble tannin content, and acetaldehyde concentration remained at harvest levels in both control and 1-MCP-treated fruit (Figs. 1A, 2A, and 2C). However, when the fruit was submitted to the $\mathrm{CO}_{2}$ treatment and transferred to $20^{\circ} \mathrm{C}$, the firmness of the untreated fruit drastically decreased (Fig. 1B). The softening is a symptom of CI, which is manifested when fruit is transferred from low to moderate temperature (Arnal and Del Río, 2004a; Salvador et al., 2006). After $10 \mathrm{~d}$ at $1{ }^{\circ} \mathrm{C}$ plus the shelf life period at $20^{\circ} \mathrm{C}$, firmness values

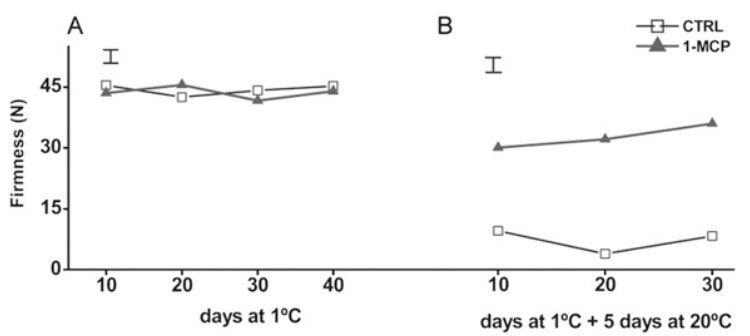

Fig. 1. Firmness of untreated control (CTRL) and 1-methylcyclopropene-treated (1-MCP) 'Rojo Brillante' persimmons during cold storage at $1{ }^{\circ} \mathrm{C}(\mathbf{A})$ and after removing astringency plus shelf life of $5 \mathrm{~d}$ at 20 ${ }^{\circ} \mathrm{C}($ B). Firmness value at harvest: $47.2 \mathrm{~N}$. Vertical bars represent least significant difference intervals $(P=0.05)$.
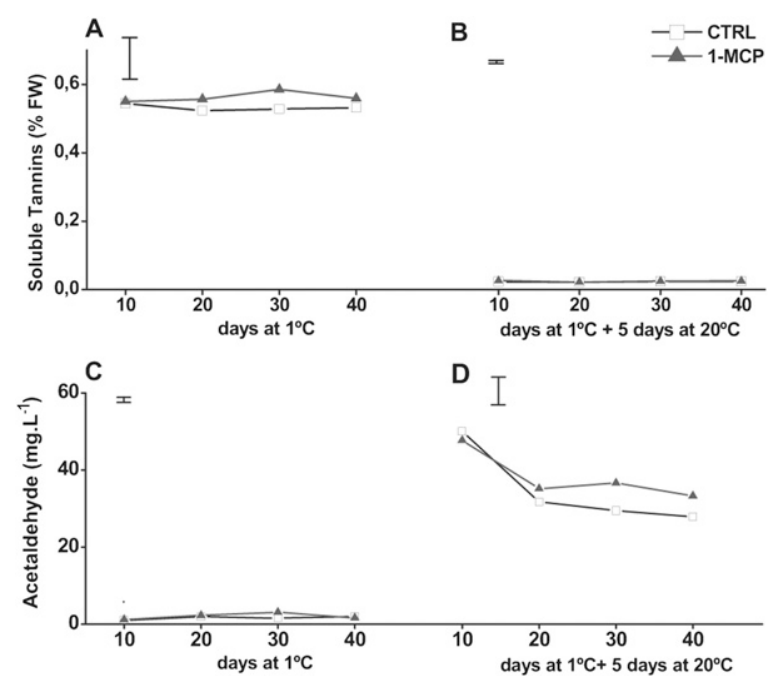

Fig. 2. Soluble tannins content and acetaldehyde concentration of untreated control (CTRL) and 1methylcyclopropene-treated (1-MCP) 'Rojo Brillante' persimmons during cold storage at $1{ }^{\circ} \mathrm{C}(\mathbf{A}, \mathbf{C})$ and after removing astringency plus shelf life of $5 \mathrm{~d}$ at $20^{\circ} \mathrm{C}(\mathbf{B}, \mathbf{D})$. Soluble tannins content at harvest: $0.6 \%$ fresh weight. Acetaldehyde at harvest: $0.9 \mathrm{mg} \cdot \mathrm{L}^{-1}$. Vertical bars represent least significant difference intervals $(P=0.05)$.

of control fruit were $\approx 10 \mathrm{~N}$ (Fig. 1B). According to previous experiments, firmness values lower than $10 \mathrm{~N}$ are considered as unacceptable from a commercial point of view (Salvador et al., 2004). Therefore, untreated fruit cold stored for $20 \mathrm{~d}$ at $1{ }^{\circ} \mathrm{C}$ plus shelf life were not marketable $(9.4 \mathrm{~N})$.

Treatment with 1-MCP significantly inhibited CI, because the treated fruit showed very high firmness values $(30 \mathrm{~N})$ after $40 \mathrm{~d}$ at $1{ }^{\circ} \mathrm{C}$ plus shelf life. This effect of 1-MCP on the $\mathrm{CI}$ alleviation in persimmon coincides with previous studies on 'Rojo Brillante' (Salvador et al., 2004) as well as on other persimmon cultivars (Brackmann et al., 2003; Girardi et al., 2003; Kim and Lee, 2005; Tibola et al., 2005).

With respect to parameters linked to astringency of the fruit, the soluble tannin content sharply decreased to values close to $0.03 \%$ after fruit were treated with $\mathrm{CO}_{2}$ and transferred to $20{ }^{\circ} \mathrm{C}$ (Fig. 2B), whereas the acetaldehyde concentration increased to values higher than $28 \mathrm{mg} \cdot \mathrm{L}^{-1}$ (Fig. 2D). As mentioned, these high levels of acetaldehyde explain the important decreased of soluble tannins, responsible for the astringency, because those are polymerized by acetalde- hyde to form an insoluble compound that is not astringent (Matsuo et al., 1991; Taira et al., 1997). Previous studies on this cultivar have linked soluble tannin content of $0.03 \%$ as well as concentration of acetaldehyde higher than $25 \mathrm{mg} \cdot \mathrm{L}^{-1}$ to nonastringent fruit when sensory properties are evaluated (Salvador et al., 2007). In the present work, the deastringency treatment was completely effective in treated and non-1-MCP-treated fruit.

The flesh microstructure by SEM of control and 1-MCP-treated fruit stored for $30 \mathrm{~d}$ at $1{ }^{\circ} \mathrm{C}$ is shown in Figures $3 \mathrm{~A}$ and $3 \mathrm{~B}$, respectively. In these samples, the formation of many precipitates generated by the chemical interaction between soluble tannins present in these cells and the glutaldehyde used in SEM procedure can be observed. Salvador et al. (2008) have already reported this kind of artefacts originating from glutaldehyde used during the preparation of the sample. Also, Yonemori and Matsushima (1987) described the appearance of precipitates from coagulated internal contents of tannin cells caused by fixatives.

As mentioned, the flesh firmness does not reflect differences between the control and 1-MCP-treated fruit during storage at $1{ }^{\circ} \mathrm{C}$; 
however, the microstructural study showed notable differences between treatments; although the precipitates partially disguise the cellular structure, in the samples treated with 1-MCP (Fig. 3B), the cell walls appeared less degraded than in control fruit (Fig. 3A). Besides, closer contact between the cell wall of adjacent cells and a more
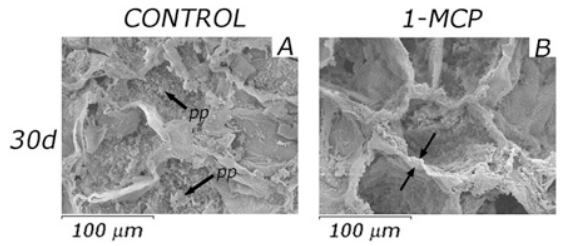

Fig. 3. Effect of 1-methylcyclopropene (1-MCP) on the structure by scanning electron microscopy from flesh samples of persimmon cv. Rojo Brillante stored at $1{ }^{\circ} \mathrm{C}$ for $30 \mathrm{~d}$. Arrows indicate contact between the cell wall of adjacent cells. $\mathrm{pp}=$ precipitate inside of the cells .
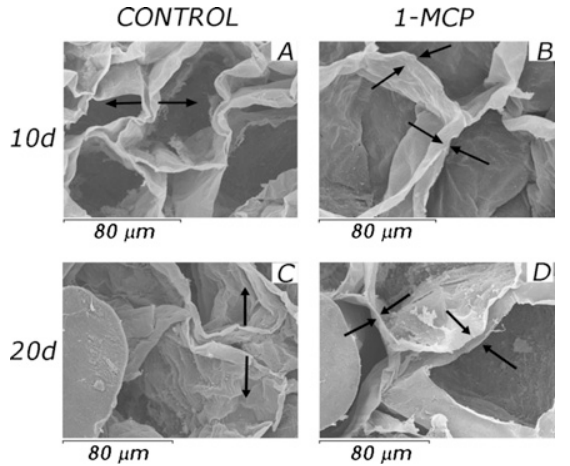

Fig. 4. Effect of 1-methylcyclopropene (1-MCP) on the structure by scanning electron microscopy from flesh samples of persimmon cv. Rojo Brillante stored at $1^{\circ} \mathrm{C}$ for $10(\mathbf{A}-\mathbf{B})$ and $20 \mathrm{~d}$ (C-D) plus deastringency treatment and shelf life of $5 \mathrm{~d}$ at $20^{\circ} \mathrm{C}$. Arrows indicate contact or loss of adhesion between the cell wall of adjacent cells.

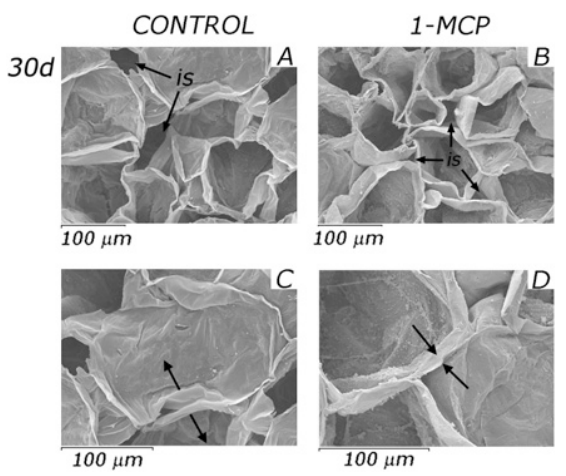

Fig. 5. Effect of 1-methylcyclopropene (1-MCP) on the structure by scanning electron microscopy from flesh samples of persimmon cv. Rojo Brillante stored at $1{ }^{\circ} \mathrm{C}$ for $30 \mathrm{~d}$ plus deastringency treatment and shelf life of $5 \mathrm{~d}$ at $20^{\circ} \mathrm{C}$. (C-D are magnified images from $\mathbf{A}-\mathbf{B})$. is = intercellular spaces; arrows = contact or loss of adhesion between the cell wall of adjacent cells. intact cell structure is observed in treated fruit than in the samples nontreated with 1-MCP.

The flesh microstructure of fruit stored at $1{ }^{\circ} \mathrm{C}$ during 10,20 , and $30 \mathrm{~d}$, submitted to the deastringency treatment plus a shelf life period of $5 \mathrm{~d}$ at $20^{\circ} \mathrm{C}$, is shown in Figures 4 and 5. It must be pointed out that the SEM observations of these samples do not show the precipitates observed in the samples immediately after storage at $1{ }^{\circ} \mathrm{C}$ during 30 d (Fig. 3). After deastringency treatment and therefore after soluble tannins being polymerized, the glutaldehyde used in the SEM procedure is not able to interact with insoluble tannins.

In Figures 4A and 4B, the parenchyma cells of fruit stored for $10 \mathrm{~d}$ at $1^{\circ} \mathrm{C}$ plus $5 \mathrm{~d}$ at $20{ }^{\circ} \mathrm{C}$ can be observed. A point to remark is that the cellular walls are not so closely united in the control samples (Fig. 4A) as those treated with 1-MCP (Fig. 4B), which would indicate a higher intercellular adhesion in those samples.

After $20 \mathrm{~d}$ at $1{ }^{\circ} \mathrm{C}$ plus $5 \mathrm{~d}$ at $20^{\circ} \mathrm{C}$ (Fig. $4 \mathrm{C}-\mathrm{D}$ ), notable changes can be observed between the 1-MCP-treated samples (Fig. 4D) and the control samples (Fig. 4C). Clearly, the tissue of samples treated with $1-\mathrm{MCP}$ maintained a greater integrity.

After $30 \mathrm{~d}$ at $1{ }^{\circ} \mathrm{C}$ plus $5 \mathrm{~d}$ at $20^{\circ} \mathrm{C}$, non 1 MCP-treated samples (Fig. 5A) show cellular tissue with many intercellular spaces and larger than the treated samples (Fig. 5B), which would reflect the loss of intercellular adhesion. At higher magnification (Fig. 5CD), samples treated with 1-MCP clearly show cell walls closely united (Fig. 5D).

The cellular structure of 1-MCP-treated samples did not display any perceptible changes after 10, 20, and $30 \mathrm{~d}$ of storage at $1{ }^{\circ} \mathrm{C}$ plus shelf life simulation (Figs. 4B, 4D, and 5D). This fact would explain the high firmness values shown by fruit treated with 1 MCP after the different shelf life periods studied (Fig. 1B).

The structural differences between 1MCP-treated fruit and untreated fruit could explain why the control fruit showed a drastic softening, the main symptom of CI, whereas $1-\mathrm{MCP}$ treatment markedly reduced this alteration maintaining higher firmness values at all times.

\section{Conclusions}

The flesh microstructural study of persimmon submitted to cold storage at $1{ }^{\circ} \mathrm{C}$ showed that the softening, as a symptom of $\mathrm{CI}$, is the result of the degradation of cell wall material with loss of intercellular adhesion. The 1MCP preserves the integrity of the cell walls and the adhesion between adjacent cells throughout the cold storage as well as when the fruit is transferred to shelf life temperature.

\section{Literature Cited}

Arnal, L. and M.A. Del Río. 2003. Removing astringency by carbon dioxide and nitrogenenriched atmospheres in persimmon fruit cv. Rojo Brillante. J. Food Sci. 68:1516-1518.
Arnal, L. and M.A. Del Río. 2004a. Effect of cold storage and removal astringency on quality of persimmon fruit (Diospyros kaki, L.) cv. Rojo Brillante. Food Sci. Technol. Intl. 10:179-185.

Arnal, L. and M.A. Del Río. 2004b. Quality of persimmon fruit cv. Rojo Brillante during storage at different temperatures. Span. J. Agr. Res. 2:243-247.

Brackmann, A., S.T. de Freitas, A.M. de Mello, and C.A. Steffens. 2003. Aplicação de 1-MCP em caqui 'quioto' armazenado sob refrigeração e atmosfera controlada. Revista Brasileira de Fruticultura. Jaboticabal, SP. 25:42-44. (in Portuguese).

Girardi, C.L., A. Parussolo, R. Danieli, A.R. Corrent, and C.V. Rombaldi. 2003. Conservação de caqui (diospyros kaki, 1.), cv. Fuyu, pela aplicação de 1-metilciclopropeno. Revista Brasileira de Fruticultura. Jaboticabal, SP. 25:54 56. (in Portuguese).

Grant, T.M., E.A. MacRae, and R.J. Redgwell. 1992. Effect of chilling injury on physicochemical properties of persimmon cell walls. Phytochemistry 31:3739-3744.

Harker, F.R. and S.K. Forbes. 1997. Ripening and development of chilling injury in persimmon fruit: An electrical impedance study. N. Z. J. Crop Hort. Sci. 25:149. (abstr.).

Hershkovitz, V., S.I. Saguy, and E. Pesis. 2005. Postharvest application of 1-MCP to improve the quality of various avocado cultivars. Postharvest Biol. Technol. 37:252-264.

Kim, Y.K and J.M. Lee. 2005. Extension of storage and shelf-life of sweet persimmon with 1-MCP. Acta Hort. 685:165-174.

Kubo, Y., R. Nakano, and A. Inaba. 2003. Cloning of genes encoding cell wall modifying enzymes and their expression in persimmon fruit. Acta Hort. 601:49-55.

Larrigaudiere, C., R. Vilaplana, Y. Soria, and I. Recasens. 2004. Oxidative behaviour of Blanquilla pears treated with 1-methylcyclopropene during cold storage. J. Sci. Food Agr. 84:18711877.

Luo, Z.S. 2004. Effect of 1-methylcyclopropene on persimmon fruit ripening and pectin metabolism. J. Fruit Sci. 21:229-232.

Luo, Z.S. 2007. Effect of 1-methylcyclopropene on ripening of postharvest persimmon (Diospyros kaki L.) fruit. Food Sci. Technol. 40:285-291.

Luo, Z.S. and Y.F. Xi. 2005. Effect of storage temperature on physiology and ultrastructure of persimmon fruit. J. Zhejiang Univ. Agr. Life Sci. 31:195-198.

Matsuo, T. and S. Ito. 1982. A model experiment for with high carbon dioxide: In vitro gelation of kaki-tannin by reacting with acetaldehyde. Agr. Biol. Chem. 46:683-689.

Matsuo, T., S. Ito, and R. Ben-Arie. 1991. A model experiment for elucidating the mechanism of astringency removal in persimmon fruit using respiration inhibitors. J. Jpn. Soc. Hort. Sci. $60: 437-442$

Niikawa, T., T. Inari, T. Ozeki, and B. Mitsui. 2005. Effects of 1-methylcyclopropene on flesh firmness during storage of pollination-constant and non-astringent cultivars of Japanese persimmon (Diospyros kaki). J. Jpn. Soc. Food Sci. Technol. 52:68-73.

Salvador, A., L. Arnal, C. Besada, V. Larrea, I. Hernando, and I. Pérez-Munuera. 2008. Reduced effectiveness of the treatment for removing astringency in persimmon fruit when stored at $15^{\circ} \mathrm{C}$ : Physiological and microstructural study. Postharvest Biol. Technol. 49:340 347

Salvador, A., L. Arnal, C. Besada, V. Larrea, A. Quiles, and I. Pérez-Munuera. 2007. Physiological 
and structural changes during ripening and deastringency treatment of persimmon fruit cv. Rojo Brillante. Postharvest Biol. Technol. 46:181-188

Salvador, A., L. Arnal, J.M. Carot, C.P. Carvalho, and J.M. Jabaloyes. 2006. Influence of different factors on firmness and color evolution during the storability of persimmon cv. Rojo Brillante. J. Food Sci. 71:169-175.

Salvador, A., L. Arnal, A. Monterde, and J. Cuquerella. 2004. Reduction of chilling injury symptoms in persimmon fruit cv. Rojo Brillante by 1-MCP. Postharvest Biol. Technol. 33:285-291
Taira, S. 1995. Astringency in persimmon, p. 97 110. In: Linskens, H.F. and J.F. Jackson (eds.). Fruit analysis. Springer, New York, NY.

Taira, S., M. Ono, and N. Matsumoto. 1997. Reduction of persimmon astringency by complex formation between pectin and tannins. Postharvest Biol. Technol. 12:265-271.

Tibola, C.S., L. Lucchetta, M.R. Zanuzo, P.R. da Silva, V.C. Ferri, and C.V. Rombaldi. 2005. Inibição da ação do etileno na conservação de caquis (Diospyrus kaki L.) 'Fuyu'. Revista Brasileira de Fruticultura. Jaboticabal, SP. 27:36-39.

Valdenegro, M., F.B. Flores, F. Romojaro, M. Ramírez, and M.C. Martinez-Madrid. 2005.
Susceptibility of Spanish melon fruits to chilling injury during cold storage. Acta Hort. 682:1219-1225.

Xu, C.G., A. Nakatsuka, and H. Itamura. 2004. Effects of 1-methylcyclopropene (MCP) treatment on ethylene production, softening and activities of cell wall degrading enzymes in 'Saijo' persimmon fruit after removal of astringency with dry ice. J. Jpn. Soc. Hort. Sci. 73 184-188.

Yonemori, K. and J. Matsushima. 1987. Morphological characteristics of tannin cells in Japanese persimmon fruit. J. Amer. Soc. Hort. Sci. 112:812-817. 